\title{
The Emancipation Years: Sport in the Female Colleges at the University of Sydney 1892-1958
}

\author{
Jessica Graham ${ }^{1} \&$ Steve Georgakis ${ }^{1}$ \\ ${ }^{1}$ The University of Sydney, Australia \\ Correspondence: Jessica Graham, The University of Sydney, Australia. E-mail: Jessica.graham@ @ydney.edu.au \\ Received: June 3, 2015 \\ Accepted: October 10, 2015 \\ Online Published: October 13, 2015 \\ doi:10.5430/ijhe.v4n4p216 \\ URL: http://dx.doi.org/10.5430/ijhe.v4n4p216
}

\begin{abstract}
This paper traces the development of sport in the two female residential colleges (Women's and Sancta Sophia) at the University of Sydney. While the University of Sydney male residential colleges established an intercollegiate sporting competition in 1907 (Rawson Cup), it was not until 1958 that the female residential colleges established an intercollegiate competition (Archdale-Macrae Cup). This paper traces the history of female collegiate sport leading up to the establishment of the Archdale-Macrae Cup and argues that sport was an essential part of the intercollegiate experience and spirit.
\end{abstract}

Keywords: Female sport, Sport, University of Sydney, College sport

\section{Introduction}

This paper examines an area of educational and sporting history that has been strangely neglected: the history of sport at the female colleges of Sydney University. The history of sport at these residential colleges provides insights into the educational role that sports played in female communities. Dewey (1916) noted:

Society not only continues to exist by transmission, by communication, but it may fairly be said to exist in transmission, in communication. There is more than a verbal tie between the words common, community and communication ..... What they must have in common in order to form a community or society are aims, beliefs, aspirations, knowledge - a common understanding - like-mindedness. Such things cannot be passed physically from one another like bricks; they cannot be shared as persons would share a pie by dividing it into physical pieces. (p.7)

Not only was sport at the colleges the stimulus to participation amongst the women, it also acted as an educative force, bringing about a sense of community amongst the various women who attended these colleges. In particular this paper traces the origins, developments and role of sport at the two female residential colleges at the University of Sydney. The study covers the period from 1892, when the first college, Women's College, was established, until the 1958, when an intercollegiate competition was inaugurated. While historians of education and sport have documented the sporting traditions of males in education systems: schools (Sherington, 1983; Sherington, Petersen \& Brice, 1987) and universities (Hickie, 1998), the sporting traditions of women in educational institutions and the link between women and education, has not been deemed worthy of investigation in the Australian scene. What does exist is sporadic references to sport in the international setting. McCrone (1984) who focused on female residential colleges in England noted that collegiate women were first introduced and learned to appreciate sports at places such as Oxford and Cambridge. The founders of the women's university colleges believed that women had a right to develop their bodies as well as their minds, and they sought to keep students as fit as possible in order to prove that women could endure, without damage the strain of solid learning. The women colleges at Cambridge were Girton (1869), Newnham (1871); while at Oxford there were Lady Margaret Hall (1879), Somerville (1879), St Hugh's (1886) and St Hilda (1893) and it was quite clear that these colleges sanctioned sport.

This paper is located in the history of education field and has employed history of education methodology. History of education methodology "seeks to advance our understanding of theoretical and methodological considerations relating to the history of education" (McCulloch \& Watts, 2003, p.129). Due to the paucity of literature directly related to women's college sport, the authors conducted extensive archival research, and these primary source documents included magazines, calendars, photographs, newsletters, letters, memoranda, recordings and other memorabilia. 


\section{Women's College}

Even though males entered Sydney University in 1852, the first two female students did not commence their study until 1882. Turney, Bygott \& Chippendale (1991) recognized the importance of women entering Sydney University as a significant marker of progress in the fight for emancipation. They conclude:

In education the most important thing was to gain women the right to higher education at University...once they had gained a University education, women immediately became eligible for all sorts of careers. (p.237)

The women who undertook study at Sydney University were much more fortunate than their counterparts overseas. For example in England, women were not admitted to Oxford University until 1920, while Cambridge University didn’t admit women until 1948 (Prest, 1993). Unlike other universities, women at Sydney University were not only granted the right to study but were also granted the right to graduate with the same qualifications as men (Hole \& Treweeke, 1953).

Women's College was the first female college established at Sydney University in 1892. The inaugural intake was eight students and in those first years remained small in numbers. While Women's College was not completed until 1894, included in the plans was the allocation of two asphalt tennis courts to be built within the grounds (Hole, \& Treweeke, 1953,). This indicates on the one hand, that in 1892, women were playing tennis at the University and, on that other hand, that tennis was seen as such an important activity for the girls that two tennis courts should be included in the building of Women's College (Hole, \& Treweeke, 1953).

Many sections of the country, including doctors and educationalists, believed that women playing sport would jeopardize their capacity to bear children. It was suggested that women who participated in strenuous physical activity would risk damaging their reproductive organs and therefore their ability to have children (Adair \& Vamplew, 1997). Since the belief that sport jeopardized a girl's chances of motherhood was widely accepted within society at this time, the role of Women's College, in questioning this notion, can be seen to be especially influential in liberating female students through encouraging their participation in sport. From the first year of its existence, sport was sanctioned by Women's College's management. For example, the first principal, Louisa MacDonald, an Englishwoman was well versed in the larger social movements for female emancipation including the Womanhood Suffrage League of New South Wales and the Women's Literary Society, promoted sport (Alexander, 1986).

Sport in this period was used as a way to emancipate women at the University. Its primary motivation was concerned with giving women the same opportunities afforded to men. As soon as the courts were completed, the Women's College Tennis Club was established in 1894 (Women's College, 1894). Tennis was the principal game in Women's College in the first decade. Women's College students were highly involved and when Sydney University sent a female tennis team to play in the first intervarsity encounter against Melbourne University in 1914, the team was completely comprised of students from Women's College (Women's College, 1914).

A major development in the tennis was the introduction of the Dickinson Cup. The Dickinson Cup was initiated "as a remembrance of the keen interest taken by Dr. Dickinson during her residence in College in the sports and physical training of the students, and will be held by the champion tennis player of the year" (Women's College, 1913, p.8). The Cup was presented annually to the champion tennis player at the Women's College. Evelyn Dickinson whilst residing in the Women's College, studied medicine, and upon graduating, became the Women's College physician (Hole \& Treweeke, 1953). She was the epitome of the "new woman", wearing her hair short and writing a number of controversial novels that presented advanced ideas for their time (Hole \& Treweeke, 1953). More importantly, Evelyn Dickinson was a keen sports promoter, following her wishes "the little room under the tower was fitted up as a gymnasium for her use, and here she initiated some of the students into the process of keeping fit" (Hole \& Treweeke, 1953, p.98).

Participation in sport for women was more about participation and Women's College students were actively encouraged to assist the development of sport beyond the confines of just the Women's College, extending their efforts to Sydney University in general. This can be attributed to two reasons. First, the numbers within the Women's College itself were not great enough to have internal competition. Second, the fact that they were the only female college left them with no one to compete against, unlike the competition available to the numerous male colleges. Therefore, students of the Women's College participated in University sports and became central to the development of the University women's sport. This is particularly evident in the establishment of the various University women's sporting clubs. Lilienthal (1997), for example, noted that the Women's College was the sole influence on the development of the Sydney University Women's Boat Club in 1896, which occupied over $80 \%$ of the club's office 
between 1899 and 1907. In fact, Evelyn Dickinson, an integral member of the Women's College, was the initiator of the University Women's Boat Club (Lilienthal, 1997).

Once the female students had established their tennis and boat clubs, the women wanted to move onto more physically demanding masculine sports such as cricket and hockey. The Sydney University Women's Hockey Club was established in 1908 as a result of this push into historically male sporting domains. Women's College was heavily involved in the hockey competitions running within Sydney University, and, as well, the Women's College had three of its students selected to play and represent New South Wales' first state hockey team in 1914 (Women's College, 1914). Once again this highlights the importance placed on Sydney University competitions and the important role Women's College students played in the development of women's sport at Sydney University. Once the Sydney University hockey club consolidated its position, the Women's College hockey club was established in 1916. Jessie Street was the leading light in this club and in 1916, the College team only lost one game (Radi, 2002; Street, 2004).

Sporting women were liberated around the University during the WWI period. During this period, sports competitions for women, such as the competition for the Dickinson Cup, continued. The only sports competitions to cease for women during WWI were the intervarsity competitions due to of the expense of travel. Surprisingly, while all male sport at the University was suspended for the duration of WWI, sport for women flourished during this period (Sherington \& Georgakis, 2008).

Post-WWI brought a number of changes and developments. Whilst traditional competitions continued, new sports and sports competitions were introduced. Netball and athletics were introduced within the Women's College for female students to actively participate in. The annual 'Athletics meeting' was introduced in 1923 (Women's College, 1923). This represented a new form of sports competition that was open only to students of the Women's College (Women's College, 1923). The first such competition took place in 1923 and by 1924, the reward for this competition was the 'Sports Championship Cup', was awarded to the student with the highest individual point score (Women's College, 1924).

The building of a netball court at the Women's College in 1923 saw a new sport being developed within the College (Women's College, 1923) and "enthusiastic players practiced in the early hours of the morning during the winter" (Women's College, 1923, p.7). The launching of the new court coincides with the inception of recording of netball games and netball results in Women's College archives. In that first year, according to Women's College, (1923), the Women's College team defeated the Sydney University team. This then led to the formation of the first Sydney University Netball team to play in the intervarsity competition. Once again most of the team was made up of students from the Women's College (Women's College, 1923).

\section{Sancta Sophia College}

Perhaps the most notable development in the post-WWI period was the impact of increasing female enrolments at Sydney University; in 1900 there were 81 female students and by 1920 there were 605 female students enrolled (Turney, et.al., 1991). Due to both this increase and to the advancement of education for women, momentum gathered to build another female college. In November 1923, the Catholic Archbishop of Sydney, Michael Kelly and the Bishops of New South Wales:

Called a meeting of the N.S.W bishops on November 19, 1923 at the Cathedral where he proposed that the Catholic Women's College would be built by all the dioceses in N.S.W. (Kennedy, 1997, p.47)

On March 15, 1926, the first students moved into the new Hall, with 23 students in total residing in Sancta Sophia in its first year. The establishment of Sancta Sophia meant that there were now two female colleges at the University of Sydney. Not surprisingly, this had a positive effect on the development of intercollegiate sport for women. Previously, Women's College had limited competition and numbers to draw from, as well as limited teams to play against. The founding of a second college meant that a new era of sport for the women's colleges was established. The new competitions and new traditions that were born at this time, continued to be developed and utilized over decades to come. In the first year of Sancta Sophia's existence, in 1926, several intercollegiate events were organized (Women's College, 1926). The first of these was a tennis competition against Sancta Sophia hosted by Women's College (Women's College, 1926). The second tennis competition later that year was hosted by Sancta Sophia and resulted in Women's College winning (Women's College, 1926). Santa Sophia built two tennis courts which provided a commitment to female students' participation in sport. These tennis exchanges were followed by netball and athletics competitions (Women's College, 1926). The two women's colleges, Sancta Sophia and Women's, had begun to compete against one another and establish sporting competitions and traditions. 
Only a year after Sancta Sophia opened, Sancta attempted to establish a strong netball team to play against the Women's College in an intercollegiate competition (Sancta Sophia, 1927). By 1928, sport started to flourish at Sancta Sophia College, with the score and the will to win becoming more important. There is evidence of practice sessions being arranged and, in order for the team to have a team to train against, "non-athletic" members of the college were sometimes encouraged to practice as well (Sancta Sophia, 1928). The training paid off as Sancta Sophia defeated Women's College by "27 goals to 17" for the first time in 1928 (Sancta Sophia, 1928).

It was clear that in the early years of the college, sport was clearly sanctioned as it was part of "a sound mind in a healthy body" and that "development of muscles was an important component of education" (Sancta Sophia, 1928, p.34). At the same time, however, the actual game of tennis itself did not seem to be the main focus of the tennis competitions. Rather, the tennis parties themselves and the fashions of the time "those little silk 'kerchiefs whose function is ornament, striking a gay note among the white clad players" (Sancta Sophia, 1928, p.34) took precedence. College social activities centered around college sporting activities.

The year 1928 seems to mark the point at which Sancta Sophia College established itself amongst the other colleges with regards to sport and became more involved in the intercollegiate competitions. It was decided that there would be annual fixtures of intercollegiate competitions in tennis, netball and athletics between Sancta Sophia and the Women's College (Sancta Sophia, 1928) and the two colleges decided on alternating upon which grounds the competitions were to be held each year (Sancta Sophia, 1928). Sancta Sophia even suggested that the establishment of this organized intercollegiate sports competition "should do much to build up that friendly rivalry that is so essentially a part of the university intercollegiate spirit" (Sancta Sophia, 1928, p.34). The following year intercollegiate basketball was added as a fourth sport in which the two colleges could compete against one another (Sancta Sophia, 1930).

The women at the two colleges wanted to branch out and enter the male domain of sport, not only competing in what were considered masculine sports, but also competing against men. Women's College began to compete against the males colleges in 1929 and this move marked the start of new traditions. A mixed tennis tournament was introduced into intercollegiate competitions in 1929. Whilst the colleges had played against one another before, this mixed tennis competition was the first formally organized event in which the colleges partook. Women's College teamed up with St Paul's College to play against Sancta Sophia College and St John's College in a tennis competition for the first time (Sancta Sophia, 1930; Women's College, 1929). These mixed tennis competitions became an annual event for a number of years and marked the beginning of sporting competitions between the male and female colleges (Sancta Sophia, 1937; Women's College, 1933). The mixed doubles tennis tournament was just as much a social event as a sports competition, with men and women from all four colleges coming out to spectate and socialize. The mixed tennis tournament marked the beginning of a strong relationship in intercollegiate sport between the male and female colleges. This is evidenced by the men's colleges spectating some of the women's sporting competitions. For example, by 1933, during the annual tennis competition between Sancta Sophia and Women's College, St John's went and supported Sancta and St Paul's went along and supported the Women's College (Sancta Sophia, 1933). The competitions between the female and male colleges continued, and later in 1949, women began to play the men in sports that were considered more physically demanding, such as hockey and football. The men from Wesley College organized a hockey game against Women's College in 1949. In 1950, the Women's College took on St Paul's in a game that was considered a male sport, football (Women's College, 1950). Whilst it may have been considered a male sport, the Women's College stress that "a very feminine and frilly team of college girls tripped daintily over to St Paul's oval" to play St Paul's in the football match, and that the game was rigged by the umpire so that they tied 2-2 (Women's College, 1950, p.10).

Sport became such an integral part of the women's colleges and organized sports matches were highly competitive but also a means of socializing and networking. Sancta Sophia organized a number of netball matches with a number of different Catholic schools in 1939 (Sancta Sophia, 1939). These games with private girls' schools were competed in for two reasons. First, they provided practice to prepare Sancta Sophia to take on Women's College later on in the year. Second, they were an opportunity to make contact with Catholic girls' schools, whose students may be future residents at Sancta Sophia. Sancta Sophia began to establish an ideological primary, secondary and tertiary Catholic system for female students (Sancta Sophia, 1939). There were two aims that these competitions set out to achieve. Annual matches took place against Kincoppal, Rose Bay, Santa Sabina and S. Scholastica's (Sancta Sophia, 1949).

\section{The Archdale-Macrae Cup}

In the 1950s, there were a number of changes in Australian society and education, which not only impacted on Sydney University but also on college sport. First, there were the reforms of the Universities. Sydney University 
increased in considerable size having 3,232 students enrolled in 1942 to 9,626 students enrolled in 1950, with the number of female students enrolled at the Sydney University more than doubled (Turney, et. al, 1991, p.454). By 1950, women made up 20\% of the students enrolled at the University of Sydney (Connell et. al. 1995, p.445). Second, Australia hosted the 1956 Olympic Games and, at these Games, the golden years of women's sport 'were born'. Despite the fact that women only comprised $14 \%$ of the Australian team, they won more than $40 \%$ of the medals presented to Australia (Phillips, 1992, p.63). In addition, they won more than half of the gold medals for the Australian team (Gordon, 2008, p.359; Phillips, 1992, p.63).

Most of the names we associate with the Melbourne Olympics are female names. Heroines of the sixteenth Olympiad included 'Golden Girl' Betty Cuthbert, the experienced and durable Shirley Strickland, swimmers Dawn Fraser and Lorraine Crapp. The men contributed six gold medals in swimming and cycling (none in track and field). It is clear that, except for the extraordinary contribution of its female athletes and swimmers, Australia would not have had an exceptional Olympics in 1956. (Phillips, 1992, p.63)

This greatly impacted on college sport and injected it with considerable momentum. Instead of using sport as a means of emancipation, it was used in a similar way to the athleticism that was taking place in the male colleges, where the Rawson Cup (male intercollegiate competition) established a corporate identity. Around this time, the women's colleges established a competition similar to that of the Rawson Cup.

By 1958, intercollegiate sport was institutionalized when the two colleges competed for the Archdale-Macrae Cup (Women's College, 1958). The Archdale-Macrae Cup was to be contested through the competition of seven sports including swimming, table tennis, basketball, hockey, golf, tennis and cricket (Women's College, 1958). With the initiation of this new competition and increased interest in sporting activities, "college activities in these fields have become intensified this year than ever before" (Women's College, 1958, p.1). In the first year of the new competition, the Women's College were the victors, becoming the first holders of the Macrae-Archdale Cup.

The naming of the Archdale- Macrae Cup was by no means a coincidence. It was named after two principals, Anne June Macrae, a principal of Sancta Sophia, and Helen Elizabeth Archdale, a principal from Women's College. Helen Elizabeth Archdale was the principal of the Women's College during the years 1946 until 1957, and she was also the daughter of a suffragette. However, one of her many notable accomplishments was her role as Captain of the first women's cricket team (1934/35) to tour Australia (Hole \& Treweeke, 1953, pp.158-159). Archdale had quite a distinguished sporting career as an athlete in the English cricket team and she first visited Women's College during her tour to Australia as captain of the English cricket team (Hole \& Treweeke, 1953, pp.158-159). Anne June Macrae, aa graduate of Sydney University, became principal of Sancta Sophia in 1943 and retained her role up until 1957 (Kennedy, 1997, pp.114-117).

The serious manner of the Macrae-Archdale Cup competition is demonstrated by the rules that were established to govern both the competition and all students wishing to compete in it. These rules were put into writing in 1959. According to Women's College (1959) they included;

a. The cup donated by the intercollegiate committee for perpetual competition between the women's colleges in the University of Sydney shall be known as 'The Macrae Archdale Intercollegiate Challenge Cup'.

b. The college which wins the greatest number of cup events shall be nominated the holder of the Macrae Archdale Cup for that year and shall be entitled to hold the cup for a period of 12 months as from the beginning of the lent term.

c. The following shall be the events included in the competition for the cup swimming, Table tennis, Basketball, Hockey, Golf, Tennis and cricket

d. The necessary qualification for those taking part in the Macrae Archdale Cup shall be; any student who is resident in one of the women's colleges, who is in actual attendance at a course of lectures.

f. The dates upon which the events shall be played shall be decided at a meeting of the respective sports delegates (the senior student and two others from each college) early in the Lent term, the swimming events being held in concurrently with the Rawson Cup Swimming events.(p.37)

The above rules mark an important development in this competition in that the process of publishing rules/guidelines instantly made the competition more formal and gave it authority. The competition was no longer an informal matter 
of the students from the women's colleges organizing a few social sporting competitions; it had now become a formalized annual competition that was dictated by rules and formalities similar to that of the Rawson Cup.

With the expansion of sport within the women's colleges, there came, in turn, the development of sports committees within the individual colleges. Women's College, for instance, divided their sports committee into seven smaller sub-committees, each representing one of the seven competition sports (Women's College, 1959, p6). The Macrae-Archdale had become the sporting focus within the women's colleges (Women's College, 1960b).

\section{Conclusion}

Between 1892 until 1958 women who had been educated in the female colleges at Sydney University had not only learned to appreciate sport but also to compete. The founders of these colleges believed that females had a right to develop their bodies as well as their minds, and they sought to keep students as fit as possible in order to prove that women could endure, without damage, the strain of solid learning (p.113). The women colleges at Sydney were Women's (1892) and Sancta Sophia (1926), and it was crystal clear that sports were sanctioned.

Educational history must not be seen as a simple record of techniques and achievements. They must be seen and examined in the wider context of society. The various worlds of sport are social environments and, as Dewy (1916) a century ago wrote, a social environment:

Is truly educative in its effect in the degree in which an individual shares or participates in some conjoint activity. By doing his share in the associated activity, the individual appropriates the purpose which activates it, becomes familiar with its methods and subject matters, acquires needed skill, and is saturated with it emotional spirit. (p.26)

In this sense, the history of sport at the women's residential colleges can be seen as contributing, most significantly, to the education of generations of women at the University of Sydney.

\section{References}

Adair, D. \& Vamplew, W. (1997). Sport in Australian History Melbourne: Oxford University Press.

Alexander, H. (1986). Macdonald, Louisa 1858 - 1949. Australian Dictionary of Biography Vol.10 (pp.253-254) Melbourne: Melbourne University Press.

Connell, W.F., Sherington, G.E, Fletcher, B.H., Turney, C., \& Bygott, U. (1995). Australia's First - A History of the University of Sydney Vol. 2 1940-1990. Sydney: Hale and Iremonger.

Dewey, J. (1916). Democracy and Education. New York: Collier Press.

Gordon, H. (2008). Gold an Olympic Celebration. Melbourne: Wilkinson Publishing.

Hickie, T. V. (1998). A sense of union: a history of the Sydney University Football Club. Sydney: Playright Publishing.

Hole, W. \& Treweeke, M.(1953). The history of the women's college within the university of Sydney. Sydney: Halstead Press Pty Ltd.

Kennedy, M. (1997). Wisdom built herself a house; a history of Sancta Sophia College, University of Sydney 1926-1996. Sydney: Sancta Sophia College.

Lilienthal, S. (1997). Newtown Tarts, a history of Sydney University women's sport association 1910-1995. Sydney: Allen \& Unwin.

McCrone, K. E. (1984). Play Up! Play Up! And Play the Game! Sport at the Late Victorian Girls' Public School. The Journal of British Studies, 23(2), 106-134. http://dx.doi.org/10.1086/385820

McCulloch, G., \& Watts, R. (2003). Introduction: Theory, methodology, and the history of education. History of Education, 32(2), 129-132. http://dx.doi.org/10.1080/00467600304153

Phillips, D. (1992). Australian women at the Olympic Games. Sydney: Kangaroo Press.

Prest, J. (1993). The illustrated history of Oxford University. New York: Oxford University Press.

Radi, H. (2002). 'Street, Jessie Mary Grey (1889 - 1970)', Australian Dictionary of Biography, Volume 16, (pp 328-332). Melbourne: Melbourne University Press.

Sancta Sophia. (1927-1960). Sancta Sophia College Magazine within the University of Sydney. Sydney: Sancta Sophia. 
Sherington, G. (1983). Athleticism in the antipodes: The AAGPS of New South Wales. History of Education Review, 12(2) 13-25.

Sherington, G. \& Georgakis, S. (2008). Sydney University 1852-2007: more than just a club. Sydney: Sydney University Press.

Sherington, G., Petersen, R.C., \& Brice, I. (1987). Learning to Lead: A history of girls' and boys' corporate secondary schools in Australia. Sydney: Allen and Unwin.

Street, J. (2004). Jessie Street: a revised autobiography. Annandale: Federation Press.

Turney, C., Bygott \& Chippendale, P. (1991). Australia's First: A history of the University of Sydney Vol. 1: 18501939. Sydney: Hale and Iremonger.

Women's College. (1894-1914). The Calendar of the Women's College within the University of Sydney. Sydney: Women's College

Women's College. (1914-1960). The Magazine of the Women's College, Sydney: Women's College. 